\title{
Juvenile Hepatocellular Carcinoma in a Healthy Liver: A Case Report
}

\author{
Sachiyo Onishi ${ }^{1}$, Masahiro Tajika ${ }^{1}$, Tsutomu Tanaka ${ }^{1}$, Keisaku Yamada ${ }^{1}$, Tomoyasu Kamiya ${ }^{1}$, \\ Seiji Natsume ${ }^{2}$, Yasuhiro Shimizu ${ }^{2}$ and Yasumasa Niwa ${ }^{1}$
}

\begin{abstract}
:
Primary hepatocellular carcinoma (HCC) in patients $<30$ years old is extremely rare. In younger patients, HCC develops against a background of persistent hepatitis B virus infection. We herein report a 23-year-old woman with HCC with all-negative hepatitis virus markers developing in an apparently healthy liver. Imaging studies showed a 50-mm hypervascular mass in segment 4 of the left liver lobe, compatible with HCC. The patient underwent surgical resection. A histological examination showed the presence of poorly differentiated HCC. The patient was diagnosed with HCC developing in a healthy liver. This is an extremely rare case of non-B non-C HCC.
\end{abstract}

Key words: hepatocellular carcinoma, non-B non-C, healthy liver, juvenile hepatocellular carcinoma

(Intern Med Advance Publication)

(DOI: 10.2169/internalmedicine.8305-21)

\section{Introduction}

In Japan, primary hepatocellular carcinoma (HCC) often develops against a background of chronic hepatitis, resulting from persistent infection with hepatitis $B$ virus (HBV) or hepatitis $\mathrm{C}$ virus (HCV). Individuals over 50 years old are considered the most susceptible. However, the onset of primary HCC at a younger age is often associated with persistent HBV infection (1).

We herein report a 23-year-old woman with primary HCC who showed no findings of chronic hepatitis and for whom all hepatitis-related markers remained consistently negative.

\section{Case Report}

A 23-year-old healthy Japanese woman had normal vaginal delivery at 21 years old. One year before this presentation, she noticed an abdominal mass, visited a local doctor, and underwent a follow-up examination. On admission because of dysuria, a tumor was detected by abdominal ultrasonography (US) in her upper abdomen, and she was referred to our hospital for a further examination of the mass.
She had no family history of HCC or any other malignancy. Furthermore, she was a non-smoker and non-drinker, with no history of medications including pills or supplements. The patient also had no history of blood transfusion or trauma, such as hepatic trauma. She did not have any metabolic abnormalities, including her thyroid function based on the findings obtained either at the clinic of her own obstetrician at the time of her first child's birth or at our hospital.

On visiting our hospital, her physical characteristics were as follows: height, $159 \mathrm{~cm}$; weight, $35 \mathrm{~kg}$; and body mass index (BMI), $13.8 \mathrm{~kg} / \mathrm{m}^{2}$. She had a soft abdomen with no palpable liver or spleen, no abdominal distension, no tenderness, and no edema. Blood test results showed normal results for liver function tests (Table 1). However, some tumor markers were elevated: alpha fetoprotein, $941.8 \mathrm{ng} / \mathrm{mL}$; protein induced by vitamin $\mathrm{K}$ absence-II, 1,170 $\mathrm{mAU} / \mathrm{mL}$. These findings suggested HCC (Table 1). All HBV markers, including $\mathrm{HBsAg}$, HBsAb, and $\mathrm{HBcAb}$, were negative (Table 1). Results for anti-HCV antibody were also negative. Serum concentrations of IgG, IgM, copper, and ferritin were all normal (Table 1). The laboratory findings for the patient were negative for antinuclear antibody and antimitochondrial antibody (Table 1). The albumin level, total

${ }^{1}$ Department of Endoscopy, Aichi Cancer Center Hospital, Japan and ${ }^{2}$ Department of Gastroenterological Surgery, Aichi Cancer Center Hospital, Japan

Received: July 11, 2021; Accepted: September 2, 2021; Advance Publication by J-STAGE: October 19, 2021

Correspondence to Dr. Sachiyo Onishi, soonishi@aichi-cc.jp 
Table 1. Results of Laboratory Blood Examination on Admission.

\begin{tabular}{lclc}
\hline TP & $7.8 \mathrm{~g} / \mathrm{dL}$ & AFP & $941.8 \mathrm{ng} / \mathrm{mL}$ \\
Albumin & $4.8 \mathrm{~g} / \mathrm{dL}$ & AFP-L3 & $1.80 \%$ \\
BUN & $11 \mathrm{mg} / \mathrm{dL}$ & PIVKA-II & $1,170 \mathrm{mAU} / \mathrm{mL}$ \\
Cre & $0.49 \mathrm{mg} / \mathrm{dL}$ & CEA & $0.5 \mathrm{ng} / \mathrm{mL}$ \\
AST & $18 \mathrm{U} / \mathrm{L}$ & CA19-9 & $13.2 \mathrm{U} / \mathrm{mL}$ \\
ALT & $12 \mathrm{U} / \mathrm{L}$ & HBsAg & $(-)$ \\
$\gamma$-GTP & $16 \mathrm{U} / \mathrm{L}$ & HBsAb & $(-)$ \\
ALP & $216 \mathrm{U} / \mathrm{L}$ & HBcAb & $(-)$ \\
T-bil & $0.6 \mathrm{mg} / \mathrm{dL}$ & HCVAb & $(-)$ \\
LDH & $161 \mathrm{U} / \mathrm{L}$ & IgG & $1,179 \mathrm{mg} / \mathrm{dL}$ \\
Na & $140 \mathrm{mmol} / \mathrm{L}$ & IgM & $294 \mathrm{mg} / \mathrm{dL}$ \\
K & $3.8 \mathrm{mmol} / \mathrm{L}$ & ANA & $<40$ \\
Cl & $106 \mathrm{mmol} / \mathrm{L}$ & AMA & $<20$ \\
ChE & $263 \mathrm{U} / \mathrm{L}$ & & \\
HbA1c & $5.3 \%$ & Fe & $35.8 \mathrm{ng} / \mathrm{mL}$ \\
WBC & $9,320 / \mu \mathrm{L}$ & Cu & $107 \mu \mathrm{gg} / \mathrm{dL}$ \\
RBC & $498 \times 10^{4} / \mu \mathrm{L}$ & TC & $204 \mathrm{mg} / \mathrm{dL}$ \\
Hb & $13.8 \mathrm{~g} / \mathrm{dL}$ & TG & $55 \mathrm{mg} / \mathrm{dL}$ \\
Plt & $26.4 \times 10^{4} / \mu \mathrm{L}$ & & \\
PT-INR & $1.06 \%$ & & \\
APTT & $42.2 \mathrm{~s}$ & & \\
\hline
\end{tabular}

TP: total protein, BUN: blood urea nitrogen, Cre: creatinine, AST: aspartate aminotransferase, ALT: alanine aminotransferase, $\gamma$-GTP: $\gamma$-glutamyl transferase, ALP: alkaline phosphatase, T-bil: total bilirubin, LDH: lactate dehydrogenase, ChE: cholinesterase, WBC: white blood cell, RBC: red blood cell, Hb: hemoglobin, Plt: platelet, PT-INR: prothrombin time-international normalized ratio, APTT: activated partial thromboplastin time, AFP: alpha-fetoprotein, PIVKA-II: protein induced by vitamin $\mathrm{K}$ absence or antagonist II, HBsAg: hepatitis B surface antigen, HBsAb: hepatitis B surface antibody, HBcAb: hepatitis B core antibody, HCVAb: hepatitis C virus antibody, ANA: antinuclear antibody, AMA: anti-mitochondrial antibody, TC: total cholesterol, TG: triglyceride

bilirubin level, prothrombin time, and indocyanine green (ICG) R15 value were within normal ranges, suggesting a good hepatic reserve (Table 1).

Abdominal US showed a solitary hypoechoic tumor with clear boundaries in segment 4 of the left liver lobe. Abdominal computed tomography (CT) showed a 5-cm tumor in S4 of the liver (Fig. 1a). Multiphase CT showed a strong uptake of the contrast agent in the hepatic arterial phase (Fig. 1b), followed by washout in the portal venous phase (Fig. 1c) and the equilibrium phase (Fig. 1d). However, CT showed no findings of a central scar. Magnetic resonance imaging (MRI) showed decreased and increased signal intensities for the lesion on T1- and T2-weighted imaging, respectively, whereas diffusion restriction with a high signal intensity and a low apparent diffusion coefficient were apparent on diffusion-weighted imaging. Dynamic contrastenhanced MRI showed strong enhancement in the hepatic artery phase with subsequent washout in the portal venous and equilibrium phases and typical hypointensity in the hepatobiliary phase in segment 4 of the liver. Based on these findings, HCC of cT2NOM0 cStage II (Union for International Cancer Control Seventh Edition, UICC 7th edition) was diagnosed.

The patient underwent surgical resection of segment 4, as her hepatic reserve was considered adequate for resection. The operation and postoperative clinical course were uneventful, and the patient was discharged on postoperative day 7.

A postoperative examination of the tumor specimen showed a 50×30-mm lesion with expansive growth (Fig. 2a). A histological examination of the non-tumorous portions of the specimen showed no fibrosis (Fig. 2b), and no infiltration of inflammatory cells into the portal areas or hepatic lobules was evident (Fig. 2b). No fatty deposits were identified in hepatocytes (Fig. 2b). The pathological report indicated poorly differentiated HCC, as follows: fc (capsule formation) (+), fc-inf (infiltration) (+), sf (septum formation) (+), s0, n0, Vp1, Vv1, Va0, b0, p0, sm (-) pT2 N0 M0 p Stage II (UICC, 7th edition) (Fig. 2c).

She gave birth to her second child 15 months after surgery, and at the time of writing this manuscript, at 5 years post-operation, she has had no recurrence of the disease. We conducted follow-up investigations such as blood tests, including tumor marker evaluations, every month, abdominal US every three months, and abdominal CT every six months.

\section{Discussion}

Approximately $80 \%$ of primary liver cancers are HCC, and $80 \%$ of all HCC patients have chronic hepatitis or liver cirrhosis with persistent $\mathrm{HBV}$ or $\mathrm{HCV}$ infection and a history of alcohol intake (1-6). Recently, the incidence of nonB non-C-type HCC, which may be due to alcoholic hepatitis, nonalcoholic steatohepatitis, hemochromatosis, primary biliary cirrhosis (PBC), or drugs such as oral contraceptive pill (7-11), has been reported to be increasing. In Japan, $\mathrm{HCV}$ infection often causes chronic hepatitis or liver cirrhosis, and HCC caused by HCV often develops in middle-aged patients $(12,13)$. The frequency of HCC in patients $<35$ years old is $0.89 \%$, and only $0.14 \%$ are $<25$ years old $(6,12)$. In carcinogenesis of HCC in young patients, the roles of $\mathrm{HBV}$ DNA integration or the $\mathrm{HBV} \mathrm{HBx}$ protein have been reported $(14,15)$. HCC that occurs unrelated to hepatitis or liver cirrhosis is extremely rare (3.2\%) in Japan (12). Fibrolamellar HCC (FLC) is a special type of liver cancer $(16,17)$ that develops in young patients and is unrelated to hepatitis or liver cirrhosis. It is characterized by a large tumor with calcification and a central scar $(17,18)$.

In the present case, the patient was a young woman, at only 23 years old. Furthermore, in this case, hepatitis virusrelated markers such as $\mathrm{HBsAg}, \mathrm{HBsAb}, \mathrm{HBcAb}, \mathrm{HCVAb}$ were all negative, and neither HBV-DNA nor HCV-RNA was detected. In the postoperative examination of pathological specimens, the background liver appeared normal and no findings suggestive of chronic hepatitis were detected and the pathological findings were also different from FLC. As far as we search in Pubmed and medical journal 'Igaku 


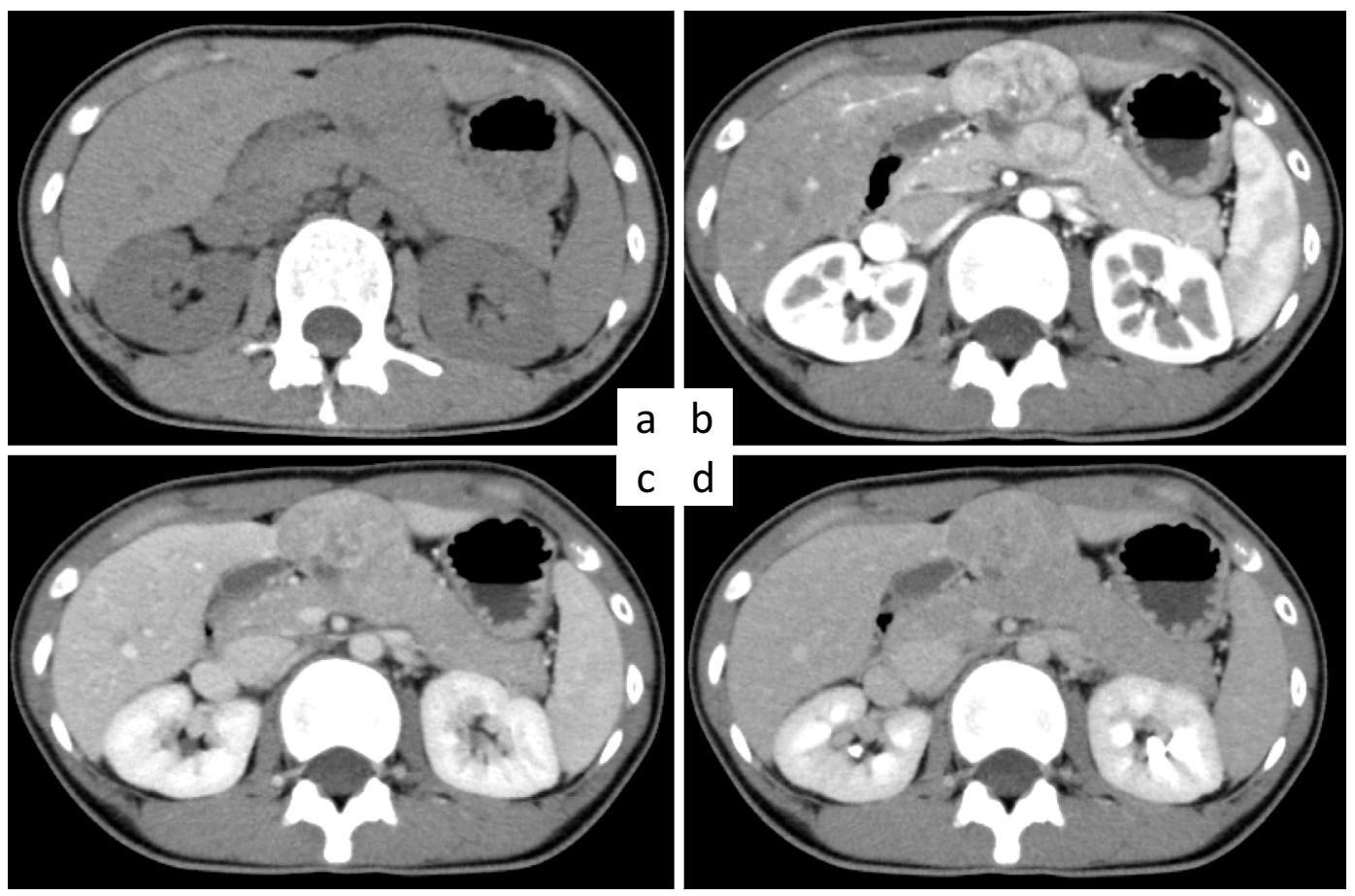

Figure 1. Multiphase computed tomography (CT) on admission showing juvenile hepatocellular carcinoma that developed in a normal liver. a) Image taken before the administration of contrast medium shows a tumor in the $\mathrm{S} 4$ segment of the liver. b-d) Findings of contrast-enhanced CT. A solid hepatic mass is seen in the S4 segment of the liver. The uptake of the contrast agent in the hepatic arterial phase (b) is strong, with subsequent washout in the portal venous phase (c) and the equilibrium phase $(\mathbf{d})$.

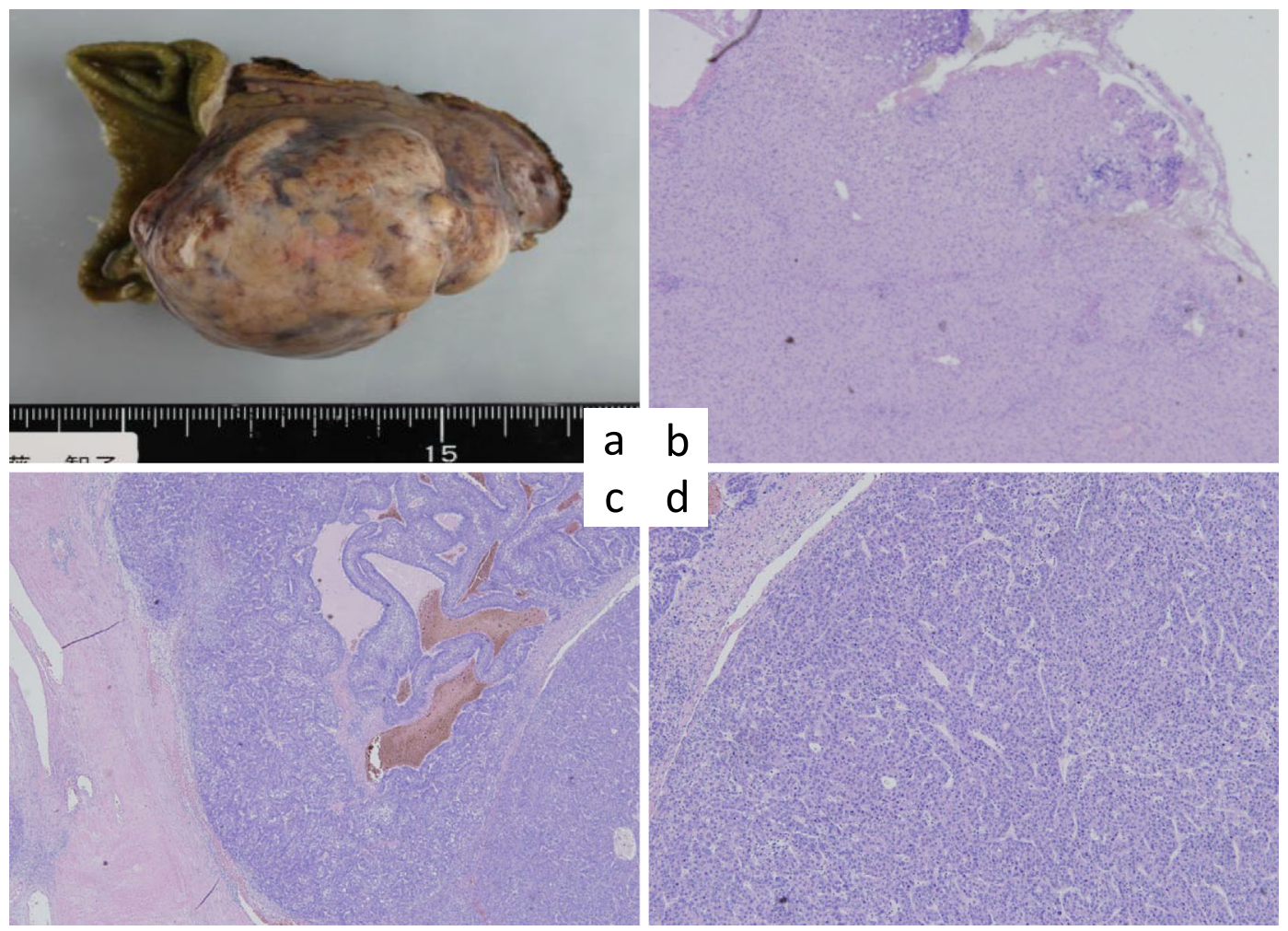

Figure 2. A postoperative examination shows a tumor $50 \times 30 \mathrm{~mm}$ in size with expansive growth. a) Resected tumor. b) Hematoxylin and Eosin $(\mathrm{H \& E})$ staining of the noncancerous portions showing no fibrosis and no inflammatory infiltration to the portal areas and hepatic lobules. c, d) H\&E staining of the tumor showing partial fatty changes, a solid nest structure, and a false duct structure, indicating poorly differentiated hepatocellular carcinoma. The tumor cells show invasion into a capsule with partial vascular invasion. 
Table 2. Juvenile Hepatocellular Carcinoma without Hepatitis Infection: Summary of Case Reports.

\begin{tabular}{|c|c|c|c|c|c|c|c|c|c|c|}
\hline No. & & Age (years) & Sex & $\begin{array}{c}\text { HBsAg/ } \\
\mathrm{Ab}\end{array}$ & $\mathrm{HBcAb}$ & HBV-DNA & $\mathrm{HCV}-\mathrm{Ab}$ & $\begin{array}{l}\text { Family } \\
\text { history }\end{array}$ & Past history & $\begin{array}{l}\text { Drinking/ } \\
\text { smoking }\end{array}$ \\
\hline 1 & Fujita $^{22)}(1995)$ & 25 & $\mathrm{~F}$ & $-/-$ & - & - & - & - & $\begin{array}{c}\text { Mycoplasma } \\
\text { pneumonia }\end{array}$ & $-1-$ \\
\hline 2 & Sato $^{23)}(1996)$ & 23 & $\mathrm{~F}$ & $-/-$ & - & - & - & $\begin{array}{l}\text { Chronic } \\
\text { hepatitis }\end{array}$ & $\begin{array}{l}\text { Congenital } \\
\text { cataract }\end{array}$ & $-/-$ \\
\hline 3 & Churiki $^{8)}(1997)$ & 17 & M & $-/-$ & - & - & - & - & $\begin{array}{l}\text { Bone } \\
\text { fracture }\end{array}$ & $-/-$ \\
\hline 4 & Nakano $^{24)}(2002)$ & 28 & M & $-/-$ & ND & - & - & - & - & $-/+$ \\
\hline 5 & Fukuii $^{25)}(2011)$ & 20 & M & $-1-$ & - & - & - & - & - & ND/ND \\
\hline 6 & Kaibori'i ${ }^{26)}(2007)$ & 20 & M & $-/-$ & - & - & - & - & $\begin{array}{l}\text { Precocious } \\
\text { puberty }\end{array}$ & $\mathrm{ND} / \mathrm{ND}$ \\
\hline 7 & Okamoto $^{27)}(2010)$ & 25 & $\mathrm{~F}$ & $-/-$ & - & ND & - & ND & Epilepsy & $\mathrm{ND} / \mathrm{ND}$ \\
\hline 8 & Kitagawa $^{28)}(2014)$ & 25 & $\mathrm{~F}$ & $-/-$ & - & - & - & - & Ovarian cyst & $-/-$ \\
\hline 9 & $\operatorname{Carla}^{29)}(2009)$ & 26 & $\mathrm{~F}$ & $-/-$ & - & ND & ND & ND & ND & ND \\
\hline 10 & Tanaka $^{30)}(1996)$ & 39 & $\mathrm{~F}$ & $-/-$ & - & - & - & ND & ND & $-/-$ \\
\hline 11 & Herath $^{31)}(2017)$ & 41 & M & $-/-$ & - & - & - & - & - & $-/-$ \\
\hline 12 & $\operatorname{Sanada}^{32)}(2004)$ & 31 & $\mathrm{~F}$ & $-1-$ & - & - & - & ND & $\begin{array}{l}\text { Pyogenic } \\
\text { spondylitis }\end{array}$ & ND \\
\hline 13 & $\mathrm{Kubo}^{33)}(2007)$ & 31 & M & $-/-$ & - & - & - & - & Appendicitis & $+/-$ \\
\hline 14 & Zubin $^{34)}(2014)$ & 40 & $\mathrm{~F}$ & $-/-$ & ND & - & - & - & - & $-/ N D$ \\
\hline 15 & Sunagawa $^{35)}(2013)$ & 26 & M & $-/-$ & - & - & - & - & - & $+/+$ \\
\hline 16 & $\mathrm{Abe}^{36)}(2019)$ & 30 & M & $-/-$ & - & - & - & - & Asthma & $-/ N D$ \\
\hline 17 & Hashimoto $^{37)}(2021)$ & 20 's & M & $-/-$ & - & - & - & - & - & $-/-$ \\
\hline 18 & Onishi & 23 & $\mathrm{~F}$ & $-/-$ & - & - & - & - & - & $-/-$ \\
\hline No. & & $\begin{array}{l}\text { Transfusion } \\
\text { recording }\end{array}$ & Drug & AFP & PIVKAII & Treatment & Recurrence & $\begin{array}{l}\text { Outcome } \\
\text { (after } \\
\text { treatment) }\end{array}$ & & \\
\hline 1 & Fujita $^{22)}(1995)$ & - & ND & 35,200 & 14.4 & TAE & No recurrence & $\begin{array}{l}\text { Alive } 11 \\
\text { months }\end{array}$ & & \\
\hline 2 & Sato $^{23)}(1996)$ & - & - & 10,320 & Normal & TAE & $\begin{array}{l}\text { Brain metastasis } \\
\quad(2 \text { years })\end{array}$ & $\begin{array}{c}\text { Died } 2 \\
\text { years }\end{array}$ & & \\
\hline 3 & Churiki $^{8)}(1997)$ & + & - & $<3.0$ & $<1.0$ & TAE, Ope & No recurrence & $\begin{array}{l}\text { Alive } 19 \\
\text { months }\end{array}$ & & \\
\hline 4 & Nakano $^{24)}(2002)$ & - & - & 37,000 & 18,100 & ND & No recurrence & $\begin{array}{c}\text { Died } 16 \\
\text { days }\end{array}$ & & \\
\hline 5 & Fukui $^{25)}(2011)$ & - & - & 181.8 & 75,000 & $\begin{array}{l}\text { Ope, TAE, } \\
\text { PEIT }\end{array}$ & $\begin{array}{l}\text { Intrahepatic } \\
\text { (7 months) }\end{array}$ & $\begin{array}{l}\text { Alive } 36 \\
\text { months }\end{array}$ & & \\
\hline 6 & Kaibori'$^{26)}(2007)$ & ND & ND & 25,100 & 292 & Ope & No recurrence & $\begin{array}{l}\text { Alive } 30 \\
\text { months }\end{array}$ & & \\
\hline 7 & Okamoto $^{27)}(2010)$ & ND & Phenytoin & 5,011 & 6,022 & TAE, Ope & No recurrence & $\begin{array}{c}\text { Alive } 21 \\
\text { months }\end{array}$ & & \\
\hline 8 & Kitagawa $^{28)}(2014)$ & - & - & 1.2 & 329 & Ope & No recurrence & $\begin{array}{l}\text { Alive } 108 \\
\text { months }\end{array}$ & & \\
\hline 9 & Carla $^{29)}(2009)$ & ND & ND & $>300$ & ND & $\begin{array}{l}\text { Palliative } \\
\text { chemo }\end{array}$ & No recurrence & $\begin{array}{l}\text { Died } 3 \\
\text { months }\end{array}$ & & \\
\hline 10 & Tanaka $^{30)}(1996)$ & - & - & Normal & Normal & Ope & ND & ND & & \\
\hline 11 & Herath $^{31)}(2017)$ & - & - & ND & ND & BSC & ND & $\begin{array}{l}\text { Died } 3 \\
\text { months }\end{array}$ & & \\
\hline 12 & $\operatorname{Sanada}^{32)}(2004)$ & ND & - & 4.1 & 39 & Ope & No recurrence & $\begin{array}{l}\text { Alive } 31 \\
\text { months }\end{array}$ & & \\
\hline 13 & $\mathrm{Kubo}^{33)}(2007)$ & - & - & 4.8 & 41 & Ope & ND & $\begin{array}{l}\text { Alive } 24 \\
\text { months }\end{array}$ & & \\
\hline 14 & Zubin $^{34)}(2014)$ & + & ND & ND & ND & BSC & ND & $\begin{array}{c}\text { Died } 8 \\
\text { days }\end{array}$ & & \\
\hline 15 & Sunagawa $^{35)}(2013)$ & - & - & Normal & Normal & Ope & ND & ND & & \\
\hline 16 & $\mathrm{Abe}^{36)}(2019)$ & - & - & 2.3 & 24 & ope & - & $\begin{array}{l}\text { Alive } 10 \\
\text { months }\end{array}$ & & \\
\hline 17 & Hashimoto $^{37)(2021)}$ & ND & - & 76,860 & 74,849 & Chemotherapy & ND & $\begin{array}{l}\text { Died } 9 \\
\text { months }\end{array}$ & & \\
\hline 18 & Onishi & - & - & 941.8 & 1,170 & Ope & - & $\begin{array}{c}\text { Alive } 60 \\
\text { months }\end{array}$ & & \\
\hline
\end{tabular}

M: male, F: female, ND: not described, TAE: transcatheter arterial embolization, Ope: operation, PEIT: percutaneous ethanol injection therapy, BSC: best supportive care 
Chuo Zasshi (ICHUSHI)' up to 2021, only 17 cases of non$\mathrm{B}$ non-C HCC without chronic hepatitis or liver cirrhosis in the liver have been reported (Table 2). Although approximately half of those cases involved patients who were under thirty years old, only two case, showed HCC without previous history, family history, blood transfusion history, drinking history or oral administration other than this patient. The patient was definitively underweight and BMI was low. However, her weight did not change preoperatively, and she had not experienced any changes in her body shape during her life. Further, blood testing revealed no evidence of malnutrition, and no evidence of fatty liver from malnutrition was seen in the background liver on postoperative pathology, so we do not believe that underweight status affected the development of HCC in this case. Therefore, we consider this case as extremely rare.

Recently, methods for genome-wide association analyses have advanced dramatically, and some reports have provided genomic information for HCC. However, HCC is a heterogeneous disease, with characteristics not only due to the cause, but also due to the genetic characteristics of the tumor, as the process of multicentric carcinogenesis differs between individual cases. In addition to identifying gene mutations for whole-genome sequencing, viral integration can also be identified. In recent years, not only the HBV genome, but also the adeno-associated virus type 2 genome has been reported to become integrated into HCC, and many cases without known risk factors have been reported. In our case, genome sequencing thus appears important for clarifying the genetic characteristics of carcinogenesis.

In general, HCC that develops in young patients often progresses and shows a low degree of differentiation on histology $(19,20)$. Recurrence within one year or pathological vascular invasion at the time of initial resection is said to be a factor contributing to poor prognosis at the time of recurrence (21) and follow-up within the short term using various modalities is desirable after surgical resection. In our case, vascular invasion ( Vp1, Vv1) was seen in the postoperative pathological tissue, so the risk of recurrence was considered high. We conducted follow-up observations such as blood tests including tumor markers every month, abdominal ultrasonography every three months, and abdominal CT every 6 months. As of 5 years after surgery, she is undergoing follow-up with no recurrence, and we will continue followup observation in the future.

In conclusion, we experienced present an extremely rare case of non-B non-C HCC occurred in normal liver in at 23 years old. No recurrence has been observed for 5 years, however, careful follow-up is required due to the risk of recurrence.

The authors state that they have no Conflict of Interest (COI).

\section{References}

1. Herbst DA, Reddy KR. Risk factors for hepatocellular carcinoma.
Clin Liver Dis 1: 180-182, 2012.

2. European Association, For The, Study Of, The Liver. European Organisation For Research And Treatment Of Cancer. EASLEORTC clinical practice guidelines: management of hepatocellular carcinoma. J Hepatol 56: 908-943, 2012.

3. Tomasz K. Nowicki, Karolina Markiet, Edyta Szurowska. Diagnostic Imaging of Hepatocellular Carcinoma - A Pictorial Essay. Curr Med Imaging Rev 13: 140-153, 2017.

4. Forner A, Llovet JM, Bruix J. Hepatocellularcarcinoma. Lancet 379: 1245-1255, 2012.

5. El-serag HB. Hepatocellular carcinoma: an epidemiologic view. J Clin Gastroenterol 35: S72-S78, 2002.

6. Shiratori Y, Yoshida H, Omata M. Different clinicopathological features of hepatocellular carcinoma: recent trends in Japan. Gastroenterology 127: S17-S26, 2001.

7. Farinati F, De Maria N, Marafin C, et al. Hepatocellular carcinoma in alcoholic cirrhosis: Is sex hormone imbalance a pathogenetic factor? Eur J Gastroenterol Hepatol 7: 145-150, 1995.

8. Farinati F, Floreani A, De Maria N, et al. Hepatocellular carcinoma in primary biliary cirrhosis. J Hepatol 21: 315-316, 1994.

9. Kosaka A, Takahashi H, Yajima Y, et al. Hepatocellular carcinoma associated with anabolic steroid therapy: report of a case and review of the Japanese literature. J Gastroenterol 31: 450-454, 1996.

10. Tavani A, Negri E, Parazzini F, et al. Female hormone utilization and risk of hepatocellular carcinoma. Br J Cancer 67: 635-637, 1993.

11. Bosetti C, Turati F, La Vecchia C. Hepatocellular carcinoma epidemiology. Best Pract Res Clin Gastroenterol 28: 753-770, 2014.

12. Liver Cancer Study Group of Japan. The 19th national primary liver cancer follow-up report (2006-2007).

13. Churiki M, Ikai I, Yamamoto M, et al. A case of Juvenile Hepatocellular Carcinoma without Hepatitis Infection. Nihon Shoukakibyou Gakkai Zasshi (Journal of Japanese Society of Gastroenterology) 30: 2292-2296, 1997.

14. Ali A, Abdel-Hafiz H, Suhail M, et al. Hepatitis B virus, HBx mutants and their role in hepatocellular carcinoma. World J Gastroenterol 20: 10238-10248, 2014.

15. Minor MM, Slagle BL. Hepatitis B virus HBx protein interactions with the ubiquitin proteasome system. Viruses 6: 4683-4702, 2014.

16. Lafaro KJ, Pawlik TM. Fibrolamellar hepatocellular carcinoma: current clinical perspectives. J Hepatocell Carcinoma 2: 151-157, 2015.

17. Ganeshan D, Szklaruk J, Kundra V, Kaseb A, Rashid A, Elsayes KM. Imaging features of fibrolamellar hepatocellular carcinoma. AJR Am J Roentgenol 202: 544-552, 2014.

18. Sergi CM. Hepatocellular carcinoma, fibrolamellar variant: diagnostic pathologic criteria and molecular pathology update. A primer Diagnostics (Basel) 6: 3, 2016.

19. $\mathrm{Ng}$ IO, Ng MM, Lai EC, Fan ST. Pathologic features and patients survival in hepatocellular carcinoma in relation to age. J Surg Oncol 61: 134-137, 1996.

21. Hanazaki K, Kajikawa S, Shimozawa N, et al. Survival and recurrence after hepatic resection of 386 consecutive patients with hepatocellular carcinoma. J Am Coll Surg 191: 381-388, 2000.

22. Fujita N, Yoshikawa T, Uemura M, et al. A case of juvenile hepatocellular carcinoma arising from normal liver. Nihon Shokakibyo Gakkai Zasshi 92: 1092-1097, 1995 (Abstract in English).

23. Sato $S$, Tanioka $H$, Nagata $H$, et al. A case of non-B, non-C, juvenile hepatocellular carcinoma with brain metastasis. Nihon Shokakibyo Gakkai Zasshi 93: 758-762, 1996 (Abstract in English).

24. Nakano M, Ohtsuka Y, Sugaya H, Terano A, Sasai T, Monma T. A case of rapidly progressive hepatocellular carcinoma in a juvenile patient with no serum hepatitis virus marker. Dokkyo J Med Sci 29: 177-181, 2002 (Abstract in English).

25. Fukui K, Taniguchi H, Ikoma H, et al. A case with juvenile hepa- 
tocellular carcinoma without hepatitis underwent right hepatic trisegmentectomy. Jpn J Cancer Chemother 38: 2475-2477, 2011 (Abstract in English).

26. Kaibori M, Ishizaki M, Uchida I, et al. A case of non-B, non-C, juvenile hepatocellular carcinoma. Nihon Shokakibyo Gakkai Zasshi 40: 617-622, 2007 (Abstract in English).

27. Okamoto N, Yamafuji K, Kubochi K, et al. A case of ruptured hepatocellular carcinoma having neither hepatitis B nor hepatitis C virus infection in a young adult patient. Nihon Shokakibyo Gakkai Zasshi 43: 929-934, 2010 (Abstract in English).

28. Kitagawa H, Tsuda $\mathrm{S}$, Tuboi K, et al. A case of well-differentiated hepatocellular carcinoma that developed in a normal liver on a young woman. Nihon Rinsho Gega Igakkai Zasshi (Journal of Japanese society for Clinical Surgery) 75: 190-196, 2014 (Abstract in English).

29. Assed C, Marchiori E, Zanetti G, et al. Pulmonary metastases from primary hepatocellular carcinoma in a 26-year-old patient: a case report. Cases J 2: 6256, 2009.

30. Tanaka T, Hoshino Y, Hayashi S, et al. A case of hepatocellular carcinoma in normal liver with no evidence of HBV or HCV infection. Hepatogastroenterology 43: 1390-1394, 1996.

31. Herath HM, Kulatunga A. Large hepatocellular carcinoma in a non-cirrhotic liver with peritoneal and omental metastasis in a healthy man: a case report. J Med Case Rep 11: 34, 2017.

32. Sanada H, Sueda T, Nakai S, et al. Hepatocellular carcinoma in a young woman which occurred in the liver without virus infection. Nihon Rinsho Gega Igakkai Zasshi 65: 1918-1923, 2004.

33. Kubo $\mathrm{Y}$, Itubo $\mathrm{M}$, Koike $\mathrm{K}$, et al. A young male patient with nonB-nonC hepatocellular carcinoma and concomitant focal nodular hyperplasia developed in the normal liver. Kanzo 48: 233-239, 2007 (Abstract in English).

34. Sharma ZD, Gokhale VS, Chaudhari N, Kakrani AL. An acute unusual presentation of hepatocellular carcinoma. J Cancer Res Ther 10: 401-403, 2014

35. Sunagawa H, Ogura K, Orokawa T, et al. A case of juvenile hepatocellular carcinoma without viral hepatitis. Liver Cancer 19: 2327, 2013 (Abstract in English).

36. Abe Y, Nojiri K, Mogaki M, et al. A case of hepatocellular carcinoma (with the maximum diameter of $12 \mathrm{~cm}$ ) arisen in the normal liver of a 30-year-old man. Nihon Rinsho Gega Igakkai Zasshi 80: 2067-2072, 2019 (Abstract in English).

37. Hashimoto A, Hattori A, Tanaka T, et al. A case of young hepatocellular carcinoma with non-B, non-C, non-cirrhotic background. Nihon Shokakibyo Gakkai Zasshi 118: 348-357, 2021.

The Internal Medicine is an Open Access journal distributed under the Creative Commons Attribution-NonCommercial-NoDerivatives 4.0 International License. To view the details of this license, please visit (https://creativecommons.org/licenses/ by-nc-nd/4.0/).

\section{(C) The Japanese Society of Internal Medicine} Intern Med Advance Publication 